\title{
Working memory, attention and their relationship: A theoretical overview
}

\author{
Memória de trabalho, atenção e sua relação: Um panorama teórico \\ Memoria de trabajo, atención y su relación: Una visión teórica
}

Received: 04/21/2021 | Reviewed: 04/26/2021 |Accept: 04/28/2021 | Published: 05/13/2021

\author{
Effrosyni Angelopoulou \\ ORCID: https://orcid.org/0000-0001-6559-1145 \\ N.C.S.R. Demokritos, Greece \\ E-mail: efrosynagge@yahoo.gr \\ Athanasios Drigas \\ ORCID: https://orcid.org/0000-0001-5637-9601 \\ N.C.S.R. Demokritos, Greece \\ E-mail: dr@iit.demokritos.gr
}

\begin{abstract}
It is broadly agreed that working memory and attention constitute two significant cognitive skills that are closely related. Their relationship has been proved to be intertwined and has attracted intense research interest. It is worth noting that, due to the growth of cognitive neuroscience and neuroimaging studies, there have been many fruitful steps towards further interpreting this link between working memory and attention. In this article, there has been an attempt to explore the concept of working memory and attention and delineate several theoretical options for conceptualizing their relationship. Furthermore, in this article, many neuroscientific aspects of working memory, attention, and their relationship are presented to inform the readers about these concepts and motivate them to deepen their understanding of working memory and attention. Simultaneously, the present article highlights the importance of working memory, attention, and their relationship for the individuals' proper cognitive function and, generally, their function and attitude in daily life.
\end{abstract}

Keywords: Working memory; Attention; Cognitive skills.

\section{Resumo}

É amplamente aceito que a memória de trabalho e a atenção constituem duas habilidades cognitivas significativas que estão intimamente relacionadas. O relacionamento deles tem se mostrado entrelaçado e atraiu intenso interesse de pesquisa. É importante notar que, devido ao crescimento da neurociência cognitiva e dos estudos de neuroimagem, tem havido muitos passos frutíferos no sentido de interpretar melhor essa ligação entre memória de trabalho e atenção. Neste artigo, buscou-se explorar o conceito de memória de trabalho e atenção e delinear várias opções teóricas para conceituar suas relações. Além disso, neste artigo, muitos aspectos neurocientíficos da memória de trabalho, atenção e sua relação são apresentados para informar os leitores sobre esses conceitos e motivá-los a aprofundar sua compreensão da memória de trabalho e atenção. Simultaneamente, o presente artigo destaca a importância da memória de trabalho, atenção e sua relação para a função cognitiva adequada dos indivíduos e, geralmente, sua função e atitude na vida diária.

Palavras-chave: Memória de trabalho; Atenção; Habilidades cognitivas.

\section{Resumen}

En general, se acepta que la memoria de trabajo y la atención constituyen dos habilidades cognitivas importantes que están estrechamente relacionadas. Se ha demostrado que su relación está entrelazada y ha atraído un intenso interés en la investigación. Vale la pena señalar que, debido al crecimiento de la neurociencia cognitiva y los estudios de neuroimagen, se han dado muchos pasos fructíferos para seguir interpretando este vínculo entre la memoria de trabajo y la atención. En este artículo, se ha intentado explorar el concepto de memoria de trabajo y atención y delinear varias opciones teóricas para conceptualizar su relación. Además, en este artículo, se presentan muchos aspectos neurocientíficos de la memoria de trabajo, la atención y su relación para informar a los lectores sobre estos conceptos y motivarlos a profundizar su comprensión de la memoria de trabajo y la atención. Simultáneamente, el presente artículo destaca la importancia de la memoria de trabajo, la atención y su relación para el correcto funcionamiento cognitivo de los individuos y, en general, su función y actitud en la vida diaria.

Palabras clave: Memoria de trabajo; Atención; Habilidades cognitivas. 


\section{Introduction}

"How many times have you been trying to keep in mind your goal to find some milk while being in a grocery store or to hold specific directions in mind as you plan a driving route?" Without the concept of working memory, none of these actions could have been done. In particular, working memory refers to our ability to maintain and manipulate information, necessary for an action, for short periods of time in the order of seconds. It also helps us to bridge temporal gaps between stimuli and actions with internal representations of the information (Bhandari \& Badre, 2016).

An additional question is the following: "Have you ever noticed how many stimuli competing for attention are there in an airplane cockpit?" There are lots of them: the instruments, the controls, the visual scene out of the window, as well as the messages from the tower. And the pilots play a crucial role in paying attention to all of these information sources. They could never manage to do so without this cognitive mechanism, which provides us the ability to focus on specific stimuli or locations (Goldstein, 2011).

Working memory and attention constitute two significant cognitive systems that are closely related, though they have been studied as separate constructions, as attention plays a crucial role in controlling activity, maintenance, and manipulation of working memory representations (Kiyonaga \& Egner, 2013). In fact, these two concepts interact, and their interaction is best understood by studying and interpreting the ways each process is implemented (Awh, Vogel, \& Oh, 2006).

This article aims to present an introductory overview of the realm of working memory and attention, as well as to highlight their intertwined relationship, by gleaning several theoretical approaches that are relevant to working memory and attention. The present article also reflects an effort to unite the existing scientific knowledge about these two concepts and their relationship, give rise to deeper questioning and motivate to further research.

\section{Methodology}

The present article is based on literature review, which is an effective method to summarize and present an overview of knowledge derived from a body of literature (Aromataris \& Pearson, 2014). We conducted this literature review in order to present general knowledge as well as the history of the development of knowledge about the concepts of working memory and attention and identify their relationship from existing studies (Aromataris et al., 2014). We used the following web databases to find the articles: Google Scholar, Springer, PubMed. Our research was carried out using keywords such as working memory, attention, relationship between working memory and attention. We made an attempt to use recent articles published in scientific journals. These articles were evaluated and compared thoroughly. Both the authors of the present article contributed to the conduct of this literature review.

\section{Working Memory}

Working memory is a brain system responsible for the temporary storage and manipulation of the information necessary for language comprehension, learning, and reasoning, which are complex cognitive tasks (Baddeley, 1992, 2010). Only a small amount of information can working memory hold either abstract ideas or objects that can be counted (Cowan, 2014). It has been estimated that adults' working memory capacity is in the range of 3 or 4 objects (Cowan, 2001; Luck \& Vogel, 1998; see Cowan 2016, p. 7), while preschoolers and early elementary school children can maintain in their working memory 2 or 2.5 items (Cowan, Nugent, Elliott, Ponomarev, \& Saults, 1999; Cowan, Elliott et al., 2005; Riggs, McTaggart, Simpson, \& Freeman, 2006; Simmering, 2012; see Cowan 2016, p.7).

The earliest use of the term working memory was found in the computer science literature, where is referred that in 1956 Newell and Simon introduced this term (Cowan, 2017). More specifically, to create a computer problem-solving 
program, the logic theory machine, they designed working memories, namely computer memories for temporary information retention that differed from storage memories, that is, memories for permanent information storage (Logie \& Cowan, 2015; Newell \& Simon, 1956). All information to be processed must be brought in from the storage memories to the working memories and then return (Newell \& Simon, ibid, p. 63-64).

The concept of working memory was coined in 1960 by Miller, Galanter, and Pribram in their book "Plans and the Structure of Behaviour" (Baddeley, 2010; Brown, 2018) where working memory is presented as a kind of a quick-access memory for the execution of a plan and is located in a special place in the frontal lobes of the brain (Miller, Galanter \& Pribram, 1960; see Brown, ibid, p. 141). In 1968, Atkinson and Shiffrin used this term, while Baddeley and Hitch adopted it in 1974 as the name of their multicomponent model. Additionally, Olton used it in 1979 to describe the performance of rats in an eight-arm radial maze (Baddeley, 2010).

Working memory is differentiated from short-term memory, as these two memory systems represent different cognitive functions (Aben, Stapert \& Blokland, 2012), since, according to Goldstein (2011), short-term memory is responsible for storing information for a short period of time (e.g., remembering a phone number), while working memory refers to handling information during a complex cognitive process (e.g., remembering numbers while reading a paragraph). Furthermore, working memory is differentiated from short-term memory in its number of components, namely the central executive, the visuospatial sketchpad, the phonological loop, and the episodic buffer (Goldstein, 2011).

Another difference that can be identified between short-term and working memory is related to their neurobiological and neuroimaging study. Specifically, the prefrontal cortex and even the dorsolateral prefrontal cortex (dlPFC) are associated with both short-term and working memory (Catinas, 2017). However, D'Esposito, Postle, Ballard, and Lease (1999; see Catinas, 2017, p. 7) have shown that more intense anterior-frontal cortex (dIPFC) activity is observed during tasks that require information handling, and hence the use of working memory, in relation to tasks that require only information retention, and therefore exclusive use of short-term memory.

Therefore, the more intense activity of the posterior frontal cortex (dlPFC) when performing tasks that require information manipulation, and thus, use of working memory, is due to the greater number of procedures that are required, such as attention and processing. Correlating short-term and working memory, then, concludes that these two memory systems are separate, but at the same time interdependent, since the information held by short-term memory is necessary for working memory to manipulate information, a work for which is responsible (Catinas, 2017).

\subsection{Baddeley and Hitch's working memory model}

The Baddeley \& Hitch's multicomponent working memory model arose from the inability of the Atkinson and Shiffrin's model to explain neuropsychological data that emerged in the 1970s (Baddeley, 2010), such as patients with neurological impairments, who even though had short-term memory deficits they could store information in long-term memory (Shallice \& Warrington, 1970). To address this weakness, therefore, Baddeley and Hitch proposed this model, where working memory is presented as a control system with limited information storage and processing capabilities (Baddeley \& Hitch, 1974).

According to Baddeley (2010), this working memory model is an attentional control system called the central executive, which is aided by two short-term storage systems, namely the visuospatial sketchpad and the phonological loop, for visual and verbal-acoustic material, respectively. However, this working memory model had to be completed later by a fourth component, the episodic buffer (Baddeley, 2010) to fill the need for a mechanism for combining information from various subsystems into a form of temporary representation (Baddeley, 2000). 
Specifically, the central executive is located in the heart of the working memory model and is responsible for controlling the memory operating system and integrating it with other parts of the cognitive system (Gathercole, 2008). It is of limited capacity and closely related to attention control and the regulation of the flow of information within the working memory (Gathercole, 2008; Buchsbaum \& D’Esposito, 2017), as well as retrieving material from more permanent long-term memory systems in working memory. Also, it is associated with increased activity in the frontal lobes of both brain hemispheres, and especially the prefrontal cortex (Gathercole, 2008).

The visuospatial sketchpad is responsible for the temporary storage and handling visuospatial information (Baddeley, 2000; Buchsbaum et al., 2017; Catinas, 2017; Gathercole, 2008) and their handling (Gathercole, 2008), and is associated with increased activity in the right cerebral hemisphere (Baddeley, 2000; Gathercole, 2008) in areas 6, 19, 40 and 47 (Baddeley, 2000). It forms an interface between visual and spatial information that can be accessed either through senses or from long term memory (Baddeley, 2002).

The phonological loop's first name was the articulatory loop by an emphasis on its function that focused on the control process (Baddeley, 2000). The term phonological loop was later adopted by Baddeley and Hitch to render more precisely its storage function (Baddeley, Hitch \& Allen, 2019). It is capable of holding verbal and audio information through two systems, namely the phonological storage and the subvocal rehearsal mechanism (Baddeley, 2000; Catinas, 2017), which are related to Brodmann areas 40 and 44, respectively (Baddeley, 2000). The phonological storage holds information for about 2 seconds (Saito, 2001), while the information in the phonological loop is repeated by the subvocal rehearsal mechanism to be stored in memory (Catinas, 2017).

The episodic buffer is an information storage system (Baddeley, 2000) that binds information from the visuospatial sketchpad, the phonological loop, and long term memory (Catinas, 2017) into coherent episodes, which can be consciously retrieved. It is of limited capacity (Baddeley, 2000), which depends on the number of episodes' or information chunks' that someone can hold (Baddeley, Allen \& Hitch, 2011). Also, it is controlled by the central executive (Baddeley, 2000) and provides a connection between the subsystems of working memory, the long-term memory, and the central executive, allowing interaction between them (Baddeley et al., 2011).

\section{Attention}

Attention constitutes a selection mechanism (Thiele \& Bellgrove, 2018) that is inextricably linked with cognition (Posner \& Petersen, 1990; Von Hecker \& Meiser, 2006; Zaksaite \& Tyagi, 2020) and allows choosing information processing related to a specific task over irrelevant information (Thiele \& Bellgrove, 2018). Also, it underlies our awareness of the world and the regulation of our feelings and thoughts (Singh, Singh, Tiwari, Patel, Singh \& Mishra, 2020). In particular, it selects certain events or objects to focus on, and during the information processing, it remains focused. Also, while attention focusing on an event or object, the attention distraction is inhibited. Noteworthy is the fact that these aspects of attention change developmentally throughout infancy (Roth, Conte, Reynolds \& Richards, 2020).

Posner and Petersen (1990) point out that the importance of attention lies in its role in connecting the mental level of cognitive processes with the anatomical level of neuronal activity. In addition, they suggested three basic concepts of the attention system. The first is that the attention system is anatomically separate from the data processing systems (Petersen \& Posner, 2012; Posner \& Petersen, 1990) which handle incoming stimuli, make decisions, and produce outputs (Petersen \& Posner, 2012). The second concept is that a network of anatomical areas is used by attention, while the third one is that these anatomical areas perform different functions (Posner \& Petersen, 1990).

Furthermore, Petersen and Posner (2012) emphasize the discrete anatomical basis of the attention system, namely its division into three networks, each of which represents a different set of attentional processes. These three networks, which they 
proposed in their article "The attention system of human brain" (1990), are the alerting network, the executive network, and the orienting network.

In particular, the alerting network is focused on brain stem arousal systems along with right hemisphere systems related to sustained vigilance, while the orienting network is focused on parietal cortex, and the executive network includes midline frontal/anterior cingulate cortex. However, twenty years later, the growth of cognitive neuroscience allowed the addition of two new separable executive control networks, namely the cingulo-opercular network and the frontoparietal network. The cingulo-opercular network is characterized by stable background maintenance for task performance, while the frontoparietal network is related to task switching, initiation, and adjustments within trials in real-time (Petersen \& Posner, 2012).

Additionally, attention, as has been assumed by Corbetta \& Shulman (2002; see Coombes, Higgins, Gamble, Cauraugh \& Janelle, 2009, p. 1072;) is regulated by a goal-directed, and a stimulus-driven attentional system, that both interact during their functioning (Pashler, Johnston, \& Ruthroff, 2001; see Eysenck, Derakshan, Santos \& Calvo, 2007, p. 338). The goal-directed attentional system is influenced by expectation, knowledge, and current goals and it is involved in top-down control of attention, while the stimulus-driven attentional system responds to conspicuous stimuli and it is related to bottom-up control of attention. There is an interactive relationship between these two systems (Eysenck et al., 2007).

One of the earliest theories of attention was proposed by Broadbent in 1958. According to this theory, attention functions as a filter that selects relevant out of irrelevant information for further processing (Zaksaite \& Tyagi, 2020). Later, Chun, Golomb, and Turk-Browne (2011; see Drigas \& Karyotaki, 2019, p. 169) distinguished two types of attention: internal attention and external attention. Specifically, external attention refers to the selection and modulation of sensory information (perceptual attention), while internal attention includes cognitive control, working memory contents, long term memory, task sets or response selection (central/reflective attention) (Drigas \& Karyotaki, 2019).

\section{The Relationship Between Working Memory and Attention}

Several theories conceptualize the working memory in close relation to attention. In particular, theories referring to attention as a resource assume that attention is responsible for the limited working memory capacity, while theories referring to attention as a selection mechanism do not invoke the working memory's limited capacity. Furthermore, working memory plays a significant role in controlling perceptual attention by holding templates for targets of perceptual selection.

Sperduti, Makowski \& Piolino (2016; see Karyotaki, Drigas \& Skianis, 2017, p. 230) claim that attention control procedures are complex and they reflect the ability of a person to maintain a state of alertness, stay focus for extended periods of time on specific stimuli, mainly visuospatial, as well as the ability to inhibit strong responses and regulate or supervise someone's actions. Cowan, Donnell and Saults (2013; see Logie \& Cowan, 2015, p. 320) claim that the focus of attention functions as a cauldron for the formation of new long-term memories. In fact, according to Loggie and colleagues' neuroimaging work (Parra, Della Sala, Logie \& Morcom, 2014; see Logie \& Cowan, 2015, p. 320), when there is not longterm learning involvement, and when color-shape binding relies on working memory, the regions within the parietal, temporal, and occipital cortex are activated, but not the regions within the prefrontal cortex or the medial temporal lobe.

Additionally, Thiele and Bellgrove (2018) underpin that attention serves as an information filtering mechanism, which is activated by the active behavioral goals maintained in the working memory. From this perspective, then, attention serves working memory (Thiele \& Bellgrove, 2018) something that is also proved by the fact that visual working memory affects the distribution of attention directed to a visual object that someone had memorized (Woodman, Luck \& Schall, 2007; see Kokkalia \& Drigas, 2015, p. 5). Information codification and storage in working memory reflect the degree of prolonged 
attention to a certain number of visual objects and events (Chun, 2011; see Drigas \& Karyotaki, 2019, p. 171). That is related to the significant role that working memory's central executive plays in attention control. (Baddeley \& Logie, 1999).

Moreover, Adam and deBettencourt (2019) mention fluctuations of attention and working memory, and they propose that fluctuations of sustained attention signify a unique component between attention and working memory and affect everything that an individual remembers. In fact, as they claim, these fluctuations are highly coincident, but distinct, synchronous, but not synonymous, calling for harder work to understand why and when an optimal or not state of attention affects working memory (ibid, p. 1, 4).

It is noteworthy that, according to the Knowledge Pyramid (8-layer model) (2017), the intertwined relationship between working memory and attention plays a crucial role in the conquest of the higher layers of intelligence and consciousness, and finally the top of this pyramid, namely the transcendence. In particular, cognitive skills, such as working memory, attention, perception, visuospatial processing and various executive skills serve as general tools for retrieving and managing domain-specific knowledge (Perkins \& Salomon, 1989; see Drigas \& Pappas, 2017, p. 18).

Consequently, for the individuals to move from one Knowledge Pyramid's layer to the next one, it is necessary to develop metacognitive procedures (Drigas \& Pappas, 2017), which provide us with the survival, self-development, and selfknowledge strategies, that are important for an individual's success in all areas of human life, and they contribute to the proper functioning of the human's cognitive and psychophysiological mechanism (Drigas \& Mitsea, 2020). These metacognitive procedures are defined as monitoring, regulation, and adaptation, all included in one word, namely consciousness (Drigas \& Pappas, 2017). De Brigard (2012) underlies the attention's inextricable link with consciousness, as well as Baddeley (2000) highlights the relationship between the working memory's episodic buffer and the conscious awareness.

\section{Conclusion}

Working memory and attention constitute two neuroscientific concepts that include distinct elements and functions. However, they are inextricably linked. One typical example of the relationship between working memory and attention is that visual working memory affects the distribution of attention directed to an object. Another example is that working memory's central executive is very important for attention control because prolonged attention to an object or event is affected by the processes in working memory. Furthermore, such kind of relationship between working memory and attention affects everything that an individual remembers and, simultaneously, contributes to individuals develop metacognitive procedures, and consciousness (Drigas \& Pappas, 2017) that are necessary for the improvement of their quality of life.

To conclude, the present article offers an account of working memory and attention, highlighting their significant relationship. It can be easily understood that these two concepts and their intertwined relationship play a crucial role in the proper functioning of individuals' cognitive mechanism and, generally, in their personal development. So, we are inclined to believe that the concepts of working memory and attention and their relationship need to be incorporated into human knowledge so as people to be able to improve their cognitive skills and earn many achievements in the different fields of human life. Finally, we hope this article provides readers with additional motivation to investigate this relationship through further holistic and multi-scientific research.

\section{References}

Aben, B., Stapert, S., \& Blokland, A. (2012). About the distinction between working memory and short-term memory. Frontiers in Psychology, 3(301), 1-9. https://doi.org/10.3389/fpsyg.2012.00301

Adam, K.C.S., \& deBettencourt, M.T. (2019). Fluctuations of Attention and Working Memory. Journal of Cognition, 2(1): 33, 1-4. https://doi.org/10.5334/joc.70 
Aromataris, E. \& Pearson, A. (2014). The systematic review: An Overview. American Journal of Nursing, 114(3), 53-58. https://doi.org/ 10.1097/01.NAJ.0000444496.24228.2c

Awh, E., Vogel, E.K., \& Oh, S.H. (2006). Interactions between attention and working memory. Neuroscience, 139(1), 201-208. https://doi.org/10.1016/j.neuroscience.2005.08.023

Baddeley, A. (2010). Working memory. Current Biology, 20(4), R136-R140. https://doi.org/10.1016/j.cub.2009.12.014

Baddeley, A. (2000). The episodic buffer: A new component of working memory? Trends in cognitive sciences, 4(11), 417-423. https://doi.org/10.1016/s1364 6613(00)01538-2

Baddeley, A. (1992). Working memory. Science, 255(5044), 556-559. https://doi.org/10.1126/science.1736359

Baddeley, A.D. (2002). Is working memory still working? European Psychologist, 7(2), 85-97. https://doi.org/10.1027/1016-9040.7.2.85

Baddeley, A.D., Allen, R.J., \& Hitch, G.J. (2011). Binding in visual working memory: The role of the episodic buffer. Neuropsychologia, 49(6), 1393-1400. https://doi.org/10.1016/j.neuropsychologia.2010.12.042

Baddeley, A.D., \& Hitch, G.J. (1974). Working memory. In G.A. Bower (Ed.), Recent Advances in Learning and Motivation, 8, 47-89. New York: Academic Press. https://doi.org/10.1016/S0079-7421(08)60452-1

Baddeley, A.D., Hitch, G.J. \& Allen, R.J. (2019). From short-term store to multicomponent working memory: The role of the modal model. Memory and Cognition, 47, 575-588. https://doi.org/10.3758/s13421-018-0878-5

Baddeley, A.D., \& Logie, R.H. (1999). Working memory: The multiple-component model. In A. Miyake \& P. Shah (Eds.), Models of working memory: Mechanisms of active maintenance and executive control, 28-61. Cambridge University Press. https://doi.org/10.1017/CBO9781139174909.005

Bhandari, A., \& Badre, D. (2016). A Nimble Working Memory. Neuron, 91(3), 503-505. https://doi.org/10.1016/j.neuron.2016.07.030

Brown, C. (2018). Correlation between working memory, intelligence, and cognitive functions. Journal of Alternative Medicine Research: Special Issue Equipping Minds Cognitive Development, 10(2), 139-154. Updated November https://www.researchgate.net/publication/327075430_Correlation_between_working_memory_intelligence_and_cognitive_functions

Buchsbaum, B.R., \& D' Esposito, M. (2017). Short-term and working memory systems. In J. Byrne (Ed.), Learning and Memory: A comprehensive reference, 3, 2nd edition, 263-274. Oxford: Academic Press. https://doi.org/10.1016/B978-0-12-809324-5.21081-X

Catinas, O. (2017). Exploring the effects of ageing on short-term memory performance. Thesis for BSc Hons Applied Psychology. https://doi.org/10.13140/RG.2.2.32019.32808

Coombes, S.A., Higgins, T., Gamble, K.M., Cauraugh, J.H., \& Janelle, C.M. (2009). Attentional control theory: anxiety, emotion, and motor planning. Journal of anxiety disorders, 23(8), 1072-1079. https://doi.org/10.1016/j.janxdis.2009.07.009

Cowan, N. (2017). The many faces of working memory and short-term storage. Psychonomic Bulletin and Review, 24, 1158-1170. https://doi.org/10.3758/s13423-016- 1191-6

Cowan, N. (2016). Working Memory Maturation: Can We Get At the Essence of Cognitive Growth? Perspectives on Psychlogical Science, 11(2), 239-264. https://doi.org/10.1177/1745691615621279

Cowan N. (2014). Working Memory Underpins Cognitive Development, Learning, and Education. Educational Psychology Review, 26(2), 197-223. https://doi.org/10.1007/s10648-013-9246-y

De Brigard, F. (2012). The role of attention in conscious recollection. Frontiers in Psychology 3(29), 1-10. https://doi.org/10.3389/fpsyg.2012.00029

Drigas, A., \& Karyotaki, M. (2019). Attention and its Role: Theories and Models. International Journal of Emerging Technologies in Learning (iJET), 14(12), 169-182. https://doi.org/10.3991/ijet.v14i12.10185

Drigas, A., \& Mitsea, E. (2020). The 8 Pillars of Metacognition. International Journal of Emerging Technologies in Learning (iJET), 15(21), 162-178. https://doi.org/10.3991/ijet.v15i21.14907

Drigas, A.S., \& Pappas, M.A. (2017). The Consciousness-Intelligence-Knowledge Pyramid: An 8x8 Layer Model. International Journal of Recent Contributions from Engineering Science \& IT (iJES), 5(3), 14-25. https://doi.org/10.3991/ijes.v5i3.7680

Eysenck, M.W., Derakshan, N., Santos, R., \& Calvo, M.G. (2007). Anxiety and cognitive performance: Attentional control theory. Emotion, 7(2), 336-353. https://doi.org/10.1037/1528-3542.7.2.336

Gathercole, S.E. (2008). Working Memory. In J. Byrne (Ed.), Learning and Memory: A Comprehensive Reference, 2, 1st Edition, 33-51. Oxford: Academic Press. https://doi.org/10.1016/b978-012370509-9.00179-0

Goldstein, B.E. (2011). Cognitive Psychology: Connecting Mind, Research, and Everyday Experience, Third Edition. Wadsworth: Cengage Learning.

Karyotaki, M., Drigas, A., \& Skianis, C. (2017). Attentional Control and other Executive Functions. International Journal of Emerging Technologies in Learning (iJET), 12(3), 219-233. https://doi.org/10.3991/ijet.v12i03.6587

Kiyonaga, A., \& Egner, T. (2013). Working memory as internal attention: Toward an integrative account of internal and external selection processes. Psychonomic Bulletin \& Review, 20, 228-242. https://doi.org/10.3758/s13423-012-0359-y 
Research, Society and Development, v. 10, n. 5, e46410515288, 2021

(CC BY 4.0) | ISSN 2525-3409 | DOI: http://dx.doi.org/10.33448/rsd-v10i5.15288

Kokkalia, G., \& Drigas, A. (2015). Working Memory and ADHD in Preschool Education. The role of ICT's as a Diagnostic and Intervention Tool: An Overview. I-JET, 10, 4-9. https://doi.org/10.3991/ijet.v10i5.4359

Logie, R.H., \& Cowan, N. (2015). Perspectives on working memory: introduction to the special issue. Mem Cogn 43, 315-324. https://doi.org/10.3758/s13421-015-0510-x

Snyder, H. (2019). Literature review as a research methodology: An overview and guidelines. Journal of business research, 104, 333-339. https://doi.org/10.1016/j.jbusres.2019.07.039

Newell, A., \& Simon, H.A. (1956). The logic theory machine: A complex information processing system. IRE Transactions on Information Theory, 2(3), 6179. https://doi.org/10.1109/TIT.1956.1056797

Oberauer, K. (2019). Working Memory and Attention - A Conceptual Analysis and Review. Journal of Cognition, 2(1): 36, 1-23. https://doi.org/10.5334/joc.58

Petersen, S. E., \& Posner, M. I. (2012). The attention system of the human brain: 20 years after. Annual review of neuroscience, 35, 73-89. https://doi.org/10.1146/annurev-neuro-062111-150525

Posner, M.I., \& Petersen, S.E. (1990). The attention system of human brain. Annual Review of Neuroscience, 13, 25-42. https://doi.org/10.1146/annurev.ne.13.030190.000325

Roth, K. C., Conte, S., Reynolds, G. D., \& Richards, J. E. (2020). Attention and Early Brain Development. In: R. E., Tremblay, M., Boivin, R. De V., Peters, (Eds.) Encyclopedia on Early Childhood Development [online]. http://www.child-encyclopedia.com/brain/according-experts/attention-and-early-braindevelopment. Updated September 2020. https://www.researchgate.net/publication/344239658_Attention_and_Early_Brain_Development

Saito, S. (2001). The phonological loop and memory for rhythms: An individual differences approach. Memory, 9(4-6), 313-322. https://doi.org/10.1080/09658210143000164

Shallice, T., \& Warrington, E. K. (1970). Independent functioning of verbal memory stores: A neuropsychological study. The Quarterly Journal of Experimental Psychology, 22(2), 261 -273. http://dx.doi.org/10.1080/00335557043000203

Singh, T., Singh, S.L., Tiwari, T., Patel, A., Singh, A.L., \& Mishra, T. (2020). Attention and Consciousness. Conference: IAAP Bangalore. Updated November 2020. https://www.researchgate.net/publication/345566181_Attention_and_Consciousness

Thiele, A., \& Bellgrove, M.A. (2018). Neuromodulation of Attention. Neuron, 97(4), 769-785. https://doi.org/10.1016/j.neuron.2018.01.008

Von Hecker, U., \& Meiser, T. (2006). Defocused Attention in Depressed Mood: Evidence From Source Monitoring. Emotion, 5(4), 456-463. https://doi.org/10.1037/1528-3542.5.4.456

Zaksaite, T., \& Tyagi, V. (2020). Attention. In: Runco, M., Pritzker, S. (Eds.), Encyclopedia of Creativity, 3rd edition, vol. 1. Elsevier, Academic Press, 9095. https://doi.org/10.1016/B978-0-12-809324-5.23864-9 